\title{
Neuroprotective effects of agmatine and hippocampal neuron loss in the depression
}

\author{
Meng-Yang Zhu* \\ Department of Biomedical Sciences, Quillen College of Medicine, East Tennessee State University, Johnson City, TN, USA
}

\begin{abstract}
Agmatine is an endogenous polyamine and potential neurotransmitter in the brain. This article reviewed the neuroprotective effects of agmatine on hippocampal neurons against glutamate and glucocorticoids-induced neuronal damage. As neuronal loss in the hippocampus is a characteristic of depression, the neuroprotective activity of agmatine may play important role in the pathophysiology of major depression.
\end{abstract}

The hippocampus plays a vital role in learning and contextual fear conditioning. While it influences autonomic and vegetative functions such as corticotropin secretion [1], it also is one of the most vulnerable brain regions to various insults (seizures, hypoxia-ischemia, hypoglycemia etc.). Based on these characteristics, the hippocampus is likely to be an important brain structure in the pathophysiology of depression, a disorder in which both cognitive deficits and hypercortisolemia are found [2]. Considerable evidence has revealed that morphological changes occur in the hippocampus of subjects with chronic Major Depressive Disorder (MDD) [3]. For example, postmortem brains of patients with MDD showed smaller hippocampal volumes $[4,5]$. Brain imaging (MRI) studies revealed the hippocampal atrophy in chronically depressed patients $[6,7]$.

The exact reason for hippocampal volume loss in depression remains speculative. There are several possibilities. Given neurogenesis continues in the hippocampus, especially the dentate gyrus throughout adulthood in humans and other mammalian species $[8,9]$, a decreased neurogenesis has been considered to be one factor underlying the hippocampal atrophy observed in MDD [10]. Nevertheless, chronic stress may be one important cause for such reduced neurogenesis in the hippocampus. Animals exposed to various stressors exhibit overt loss of hippocampal neurons and potently suppressed adult neurogenesis in the dentate gyrus [7]. Prolonged stress causes atrophy and death of CA3 pyramidal neurons in the rat hippocampus [11,12], which was confirmed in adult monkeys [13]. Stress also suppresses the gene expression of brain-derived neurotrophic factors (BDNF), an important neurotrophin for neurogenesis, in hippocampus [14]. Both chronic stress and elevated glucocorticoids inhibit proliferation of granule cell precursors in the dentate gyrus $[15,16]$.

Apoptosis is likely another important mechanism responsible for hippocampal volume loss in depression. As mentioned above, a reduction in numbers of neuronal and/or glia cells has been reported [17] in the hippocampus of MDD. Alternatively, such a reduction in neuronal and glia cells would occur in the face of apoptosis [18]. Support for this contention comes from recent observations demonstrating that glucocorticoid receptor activation induces apoptosis of granule cells in the hippocampus [19], where glucocorticoid receptors are enriched [20]. It has been reported that glucocorticoid receptor occupation stimulates apoptosis within the granular and hilar cell populations of the dentate gyrus [21]. Moreover, increased apoptosis has been found in peripheral blood cells in patients with MDD [22]. Many studies have demonstrated that glutamate and its NMDA Receptor (NMDA-R) are important factors for apoptosis [23]. Glutamate-mediated apoptosis involves an increase in intracellular $\mathrm{Ca}^{2+}$ concentrations above the buffering capacity of neurons, leading to toxic conditions such as oxidative and nitrosative stress. Cytotoxicity, as a result of massive Nitric Oxide (NO) formation through NO donors [24] or a $\mathrm{Ca}^{2+}$-independent and inducible form of NOS by astrocytes or microglia [25], has been established in apoptosis.

It should be noted that NO-induced cell death can be entirely blocked by agents that directly or competitively block NMDA-R channel [26]. Therefore, blocking either the NMDA-R channel or NO Synthase (NOS) to reduce excitoxicity, or reducing neuronal $\mathrm{Ca}^{2+}$ overload and thereby inhibiting cysteine proteases, would attenuate apoptosis. Taken together, agents which antagonize the NMDA-R and NO formation have potential neuroprotective and anti-apoptotic effects. Agmatine, as a novel neurotransmitter in mammals, is such an endogenous agent that blocks the NMDA Receptor (NMDA-R) channels and inhibits NOS [27]. Agmatine is an endogenous polyamine derived from enzymatic decarboxylation of L-arginine [28] and preponderantly localized in neurons [29]. Immunocytochemical studies have demonstrated that agmatine is widely distributed in brain but enriched in subcortical regions [29]. Agmatine exerts neuroprotective action by reducing the size of ischemic infarctions or the loss of cerebella neurons after focal or global ischemia in vivo. It has also been reported that agmatine fully prevents neurotoxicity produced by glutamate in cultured cerebellar granule cells. In the CA1 region of hippocampus, agmatine-like immunoreactivity primarily is present in the perikarya and dendritic profiles of pyramidal cells and in punctate processes preponderantly in stratum radiatum [30]. CA3 pyramidal cells also contain agmatine-

*Correspondence to: Meng-Yang Zhu, Department of Biomedical Sciences, Quillen College of Medicine, East Tennessee State University, Johnson City, TN 37604, USA, Tel: 423-439-6394; Fax: 423-439-2280; E-mail: zhum@etsu.edu

Received: September 25, 2018; Accepted: October 10, 2018; Published: October 15,2018 
immunoreactivity, which indicates that CA3 might be the source of agmatine-containing terminals found in CA1. Subcellularly, agmatineimmunoreactivity is affiliated primarily with tubular vesicles and mitochondria. In the hippocampal regions, agmatine is found primarily in nerve terminals forming excitatory synapses on pyramidal cells, implicating that agmatine is possibly released as a co-transmitter with l-glutamate. These cellular and subcellular localizations of agmatine provide an important structural basis for the possible involvement of agmatine in the pathophysiological alteration of hippocampus in depression.

Although the study of the possible physiological functions of agmatine in the brain is stillin itsinfancy, accumulating evidenceindicates several levels of pharmacological and physiological importance. One of the most important facts is that agmatine selectively blocks NMDA-R channels in hippocampal neurons in a concentration- and voltagedependent manner [31]. Agmatine is also a competitive inhibitor of all isoforms of NOS [32]. As already mentioned, both the NMDA-R and $\mathrm{NO}$ are involved in neurotoxicity and apoptosis [24,25], which might contribute to hippocampal atrophy in major depression. In addition, there is a growing body of preclinical research showing that NMDA-Rs are altered in MDD and normalized by antidepressant treatments [33]. This is based on observations that various antidepressant treatments change the characteristics of NMDA-R subunits [34]. NMDA-R antagonists, like eliprodil and MK-801, have been shown to robustly decrease depressive symptoms in animal models of depression and in patients with MDD [35,36].

Actually, the neuroprotective action of agmatine has been observed in various neuronal injuries beyond major depression. For example, agmatine attenuates the extent of neuronal loss following excitotoxic spinal cord injury [37] and reduces tissue damage following spinal cord injury [38]. Agmatine exerts neuroprotection by reducing the size of ischaemic infarctions, as well as the loss of cerebellar neurons after focal or global ischemia [39,40]. Olmos et al [41] have reported that agmatine fully prevents neurotoxicity produced by glutamate in cerebellar granule cells. The studies from our laboratory demonstrated that agamtine protected cultured hippocampal neurons against cell damage induced by NMDA, glutamate [42], and glucocorticoids [43]. Furthermore, in vivo studies demonstrated that while chronic administration of glucocorticoids resulted in rat morphologic damage in the hippocampus, same treatment caused a parallel reduction of endogenous agmatine and arginine decarboxylase levels in rats, indicating the modulatory effects of stress hormones on endogenous agmatine [44]. This result was confirmed in the stress animal models [45], which can be protected by administration of exogenous agmatine [46]. Taken together, agmatine has neuroprotective role for the damaged hippocampal neurons.

It is noteworthy that agmatine also binds $\alpha_{2}$-adrenoceptors and is an endogenous ligand at imidazoline receptors [47]. So far there is no single report about the relationship between agmatine's neuroprotective effects and its $\alpha_{2}$-adrenoceptor properties, but an increased density of brain and platelet $\alpha_{2}$-adrenoceptor agonist binding sites has been reported in major depression and suicide [48-51]. The experimental paradigms previously performed in our laboratory and others have indicated that imidazoline binding sites are upregulated in platelets of patients with MDD and in brains of suicide victims [52,53]. In addition, agmatine has been reported to prevent the development of opioid tolerance [54] and alleviate pain associated with excitotoxic lesions in the spinal cord [37]. Although these functions may not be related to hippocampal neuronal damage in MDD, they indicate that agmatine has broad biochemical and physiological implications.

\section{References}

1. Jacobson L, Sapolsky R (1991) The role of the hippocampus in feedback regulation of the hypothalamic-pituitary-adrenocortical axis. Endocr Rev 12: 118-134. [Crossref]

2. Rubin RT (1989) Pharmacoendocrinology of major depression. Eur Arch Psychiatry Neurol Sci 238: 259-267. [Crossref]

3. Sheline YI (2000) 3D MRI studies of neuroanatomic changes in unipolar major depression: the role of stress and medical comorbidity. Biol Psychiatry 48: 791-800. [Crossref]

4. Sheline YI, Wang PW, Gado MH, Csernansky JG, Vannier MW (1996) Hippocampal atrophy in recurrent major depression. Proc Natl Acad Sci U S A 93: 3908-3913. [Crossref]

5. Sheline YI, Sanghavi M, Mintun MA, Gado MH (1999) Depression duration but not age predicts hippocampal volume loss in medically healthy women with recurrent major depression. J Neurosci 19: 5034-5043. [Crossref]

6. Shah PJ, Ebmeier KP, Glabus MF, Goodwin GM (1998) Cortical gray matter reductions associated with treatment resistant chronic unipolar depression. Controlled magnetic resonance imaging study. Br J Psychiatry 172: 527-532. [Crossref]

7. Bremner JD (1999) Does stress damage the brain? Biol Psychiatry 45: 797-805. [Crossref]

8. Eriksson PS, Perfilieva E, Bjork-Eriksson T, Alborn AM, Nordborg C, et al. (1998) Neurogenesis in the adult human hippocampus. Nat Med 4: 1313-1317. [Crossref]

9. Gould E, Reeves AJ, Graziano MS, Gross CG (1999) Neurogenesis in the neocortex of adult primates. Science 286: 548-552. [Crossref]

10. Jacobs BL1, van Praag H, Gage FH (2000) Adult brain neurogenesis and psychiatry: a novel theory of depression. Mol Psychiatry 5: 262-269. [Crossref]

11. Sapolsky RM (1996) Why stress is bad for your brain. Science 273: 749-750. [Crossref]

12. McEwen BS (1999) Stress and hippocampal plasticity. Annu Rev Neurosci 22: 105 122. [Crossref]

13. Gould E, Tanapat P, McEwen BS, Flügge G, Fuchs E (1998) Proliferation of granule cell precursors in the dentate gyrus of adult monkeys is diminished by stress. Proc Natl Acad Sci U S A 95: 3168-3171. [Crossref]

14. Duman RS, Heninger GR, Nestler EJ (1997) A molecular and cellular theory of depression. Arch Gen Psychiatry 54: 597-606. [Crossref]

15. Gould E, McEwen BS, Tanapat P, Galea LA, Fuchs E (1997) Neurogenesis in the dentate gyrus of the adult tree shrew is regulated by psychosocial stress and NMDA receptor activation. J Neurosci 17: 2492-2498. [Crossref]

16. McEwen BS (1996) Gonadal and adrenal steroids regulate neurochemical and structural plasticity of the hippocampus via cellular mechanisms involving NMDA receptors. Cell Mol Neurobiol 16: 103-116. [Crossref]

17. Rajkowska G, Miguel-Hidalgo JJ, Wei J, Dilley G, Pittman SD, et al. (1999) Mophometric evidence for neuronal and glial prefrontal cell pathology in major depresion. Biol Psychiatry 45: 1085-1098. [Crossref]

18. Duman RS, Malberg J, Nakagawa S, D'Sa C (2000) Neuronal plasticity and survival in mood disorders. Biol Psychiatry 48: 732-739. [Crossref]

19. Almeida OF, Conde GL, Crochemore C, Demeneix BA, Fischer D, et al. (2000) Subtle shifts in the ratio between pro- and antiapoptotic molecules after activation of corticosteroid receptor decide neuronal fate. FASEB J 14:779-790. [Crossref]

20. de Kloet ER, Vreugdenhil E, Oitzl MS, Joels M (1998) Brain corticosteroid receptor balance in health and disease. Endocr Rev 19: 269-301. [Crossref]

21. Hassan AH, von Rosenstiel P, Patchev VK, Holsboer F, Almeida OF (1996) Exacerbation of apoptosis in the dentate gyrus of the aged rat by dexamethasone and the protective role of corticosterone. Exp Neurol 140: 43-52. [Crossref]

22. Eilat E, Mendlovic S, Doron A, Zakuth V, Spirer Z (1999) Increased apoptosis in patients with major depression: A preliminary study. J Immunol 163: 533-534. [Crossref]

23. Rothstein JD, Dykes-Hoberg M, Pardo CA, Bristol LA, Jin L, et al. (1996): Knockout of glutamate transporters reveals a major role for astroglial transport in excitotoxicity and clearance of glutamate. Neuron 16: 675-686. [Crossref]

24. Nakazawa M, Uehara T, Nomura Y (1997) Koningic acid (a potent glyceraldehydes-3phosphate dehydrogenase inhibitor)-induced fragmentation and condensation of DNA in NG108-15 cells. J Neurochem 68: 2493-2499. [Crossref] 
25. Nomura Y, Kitamura Y (1993) Inducible nitric oxide synthase in glial cells. Neurosci Res 18: 103-107. [Crossref]

26. Nicotera P, Brune B, Bagetta G (1997) Nitric oxide: inducer or suppressor of apoptosis? Trends Pharmacol Sci 18: 189-190. [Crossref]

27. Reis DJ, Regunathan S (2000) Is agmatine a novel neurotransmitter in brain? Trends Pharmacol Sci 21: 187-193. [Crossref]

28. Tabor CW, Tabor H (1984) Polyamines. Annu Rev Biochem 53: 749-790. [Crossref]

29. Otake K, Ruggiero DA, Regunathan S, Wang H, Milner TA, et al. (1998) Regional localization of agmatine in the rat brain: an immunocytochemical study. Brain Res 787: 1-14. [Crossref]

30. Reis DJ, Yang XC, Milner TA (1998) Agmatine containing axon terminals in rat hippocampus form synapses on pyramidal cells. Neurosci Lett 250: 185-188. [Crossref]

31. Yang XC, Reis DJ (1999) Agmatine selectively blocks the NMDA subclass of glutamate receptor channels in cultured mouse hippocampal neurons. J Pharmacol Exp Ther 288: 544-549. [Crossref]

32. Galea E, Regunathan S, Eliopoulos V, Feinstein DL, Reis DJ (1996) Inhibition of mammalian nitric oxide synthase by agmatine, an endogenous polyamine formed by decarboxylation of argineine. Biochem J 316: 247-249. [Crossref]

33. Petrie RX, Reid IC, Stewart CA (2000) The N-methyl-D-aspartate receptor, synaptic plasticity, and depressive disorder. A critical review. Pharmacol Ther 87: 11-25. [Crossref]

34. Skolnick P, Layer RT, Popik P, Nowak G, Paul IA, et al. (1996) Adaptation of N-methylD-aspartate (NMDA) receptors following antidepressant treatment: implications for the pharmacotherapy of depression. Pharmacopsychiatry 29: 23-26. [Crossref]

35. Maj J, Rogoz Z, Skuza G, Sowinska H (1992) Effects of MK-801 and antidepressan drugs in the forced swimming test in rats. Eur Neuropsychopharmacol 2: 37-41. [Crossref]

36. Layer RT, Popik P, Olds T, Skolnick P (1995) Antidepressant-like actions of the polyamine site NMDA antagonist, eliprodil (SL-82.0715). Pharmacol Biochem Behav 52: 621-627. [Crossref]

37. Fairbanks CA, Schreiber KL, Brewer KL, Yu CG, Stone LS, et al. (2000) Agmatine reverses pain induced by inflammation, neuropathy, and spinal cord injury. Proc Natl Acad Sci U S A 97: 10584-10589. [Crossref]

38. Yu CG, Marcillo AE, Fairbanks CA, Wilcox GL, Yezierski RP (2000) Agmatine improves locomotor function and reduces tissue damage following spinal cord injury. NeuroReport 11: 3203-3207. [Crossref]

39. Maiese K, Pek L, Berger SB, Reis DJ (1992) Reduction in focal cerebral ischemia by agents acting at imidazole receptors. J Cereb Blood Flow Metab 12: 53-63. [Crossref]

40. Gilad GM, Salame K, Rabey JM, Gilad VH (1996) Agmatine treatment is neuroprotective in rodent brain injury models. Life Sci 58: PL 41-46. [Crossref]

41. Olmos G, DeGregorio-Rocasolano N, Paz Regalado M, Gasull T, Assumpció Boronat $M$, et al. (1999) Protection by imidazoline drugs and agmatine of aglutamate-induced neurotoxicity in cultured cerebellar granule cells through blockade of NMDA receptor. Br J Pharmacol 127: 1317-1326. [Crossref]
42. Wang WP, Iyo AH, Miguel-Hidalgo J, Regunathan S, Zhu MY (2006) Agmatine protects against cell damage induced by NMDA and glutamate in cultured hippocampal neurons. Brain Res 1084, 210-216. [Crossref]

43. Zhu MY, Wang WP, Bissette G (2006) Neuroprotective effects of agmatine against cell damage caused by glucocorticoids in cultured rat hippocampal neurons. Neuroscience 141: 2019-2027. [Crossref]

44. Zhu MY, Wang WP, Huang J, Regunathan S (2007) Chronic treatment with glucocorticoids alters rat hippocampal and prefrontal cortical morphology in parallel with endogenous agmatine and arginine decarboxylase levels. J Neurochem 103: 18111820. [Crossref]

45. Zhu MY, Wang WP, Cai ZW, Regunathan S, Ordway G (2008) Exogenous agmatine has neuroprotective effects against restraint-induced structural changes in the rat brain. Eur J Neurosci 27: 1320-1332. [Crossref]

46. Zhu MY, Wang WP, Huang J, Feng YZ, Regunathan S, et al. (2008) Repeated immobilization stress alters rat hippocampal and prefrontal cortical morphology in parallel with endogenous agmatine and arginine decarboxylase levels. Neurochem Int 53: 346-354. [Crossref]

47. Li G, Regunathan S, Barrow CJ, Eshraghi J, Cooper R, et al. (1994) Agmatine: an endogenous clonidine-displacing substance in the brain. Science 263: 966-969. [Crossref]

48. Meana JJ, Barturen F, Garcia-Sevilla JA (1992) Alpha 2-Adrenoceptors in the brain of suicide victims: increased receptor density associated with major depression. Biol Psychiatry 31: 471-490. [Crossref]

49. González AM, Pascual J, Meana JJ, Barturen F, del Arco C, et al. (1994) Autoradiographic Demonstration of increased alpha 2-adrenoceptro agonist binding sites in the hippocampus and frontal cortex of depressed suicide victims. $J$ Neurochem 63: 256-265. [Crossref]

50. Ordway GA, Widdowson PS, Smith KS, Halaris A (1994) Agonist binding to alpha 2-adrenoceptors is elevated in the locus coeruleus from victims of suicide. J Neurochem 63: 617-624. [Crossref]

51. Gurguis GN, Vo SP, Griffith JM, Rush AJ (1999) Platelet alpha2A-adrenoceptor function in major depression: Gi coupling, effects of imipramine and relationship to treatment outcome. Psychiatry Res 89: 73-95. [Crossref]

52. Garcia-Sevilla JA, Escriba PV, Ozaita A, Walzer C, Guimon J (1996) Density of imidazoline receptors in platelets of euthymic patients with bipolar depression and in brains of suicide victims. Arch Gen Psychiatry 53: 803-810.

53. Zhu H, Halaris A, Madakasira S, Pazzaglia P, Goldman N, et al. (1999) Effect of bupropion on immunodensity of putative imidazoline receptors on platelets of depressed patients. J Psychiatr Res 33: 323-333. [Crossref]

54. Fairbanks CA, Wilcox GL (1997) Acute tolerance to spinally administered morphine compares mechanistically with chronically induced morphine tolerance. J Pharmacol Exp Ther 282: 1408-1417. [Crossref]

Copyright: (C2018 Meng-Yang Z. This is an open-access article distributed under the terms of the Creative Commons Attribution License, which permits unrestricted use, distribution, and reproduction in any medium, provided the original author and source are credited. 